\title{
The reactions of acylferrocenes with samarium diiodide: reduction, deoxygenation, reductive coupling and rearrangement
}

\author{
Shean-Jeng Jong ${ }^{\mathrm{a}, \mathrm{b}}$, Jim-Min Fang ${ }^{\mathrm{a}, *}$, Chun-Hsu Lin ${ }^{\mathrm{b}}$ \\ a Department of Chemistry, National Taiwan University, Taipei, 106 Taiwan, ROC \\ ${ }^{\mathrm{b}}$ Chemical System Research Division, Chung-Shan Institute of Science and Technology, PO Box 90008-17, Lung Tan, Taiwan, ROC
}

Received 1 June 1999; received in revised form 9 July 1999

\begin{abstract}
Acylferrocenes reacted with samarium diiodide in the presence of water to give the corresponding ( $\alpha$-hydroxyalkyl)ferrocenes or alkylferrocenes depending on the reaction time and temperature. On treatment with samarium diiodide in the absence of water, ferrocenecarbaldehyde underwent a reductive coupling to give pinacols, whereas acetylferrocene yielded 3,3-diferrocenyl-2-butanone and 2,3-diferrocenyl-2-butene via the subsequent rearrangement and deoxygenation. (C) 1999 Elsevier Science S.A. All rights reserved.
\end{abstract}

Keywords: Acylferrocenes; Samarium diiodide; Reduction; Deoxygenation; Pinacol; Rearrangement

\section{Introduction}

$\mathrm{SmI}_{2}$ is a one-electron-transfer reducing agent [1], which is widely utilized to react with various functional groups. Since samarium ion is oxophilic, the reactions of $\mathrm{SmI}_{2}$ with carbonyl groups are very efficient. The generated ketyl radical anion can abstract a hydrogen atom to give alcohols, or couple with the second molecule of carbonyls to give pinacols. Such reductions and reductive couplings of aromatic carbonyl compounds have been reported [2]. Except for the property of one-electron redox [3], acylferrocenes are known to exhibit the reaction aptitude similar to aromatic carbonyl compounds in many aspects. For example, reductions of acylferrocenes are generally carried out by using $\mathrm{NaBH}_{4}$ or $\mathrm{LiAlH}_{4}$ to give the corresponding $(\alpha$-hydroxyalkyl)ferrocenes [4]. Acylferrocenes are subjected to catalytic hydrogenation to afford the corresponding alkylferrocenes [5]. Such deoxygenations are also achieved by using combined reagents [6] including $\mathrm{Na} / \mathrm{EtOH}, \quad \mathrm{Zn}(\mathrm{Hg})+\mathrm{HCl}$ (Clemmensen reduction), $\mathrm{LiAlH}_{4}+\mathrm{AlCl}_{3}, \quad \mathrm{NaBH}_{4}+\mathrm{ZnCl}_{2}, \quad \mathrm{NaBH}_{3} \mathrm{CN}+\mathrm{BF}_{3}$, $\mathrm{NaBH}_{3} \mathrm{CN}+\mathrm{TiCl}_{4}$ and $\mathrm{Et}_{3} \mathrm{SiH}+\mathrm{TiCl}_{4}$. The study of the reactions of acylferrocenes with $\mathrm{SmI}_{2}$ is so far

* Corresponding author. Fax: + 886-2-23636359. elusive. As acylferrocenes are readily available precursors viable to derivatization for the preparation of catalysts and materials [7], their reactivity towards $\mathrm{SmI}_{2}$ is worthwhile to investigate.

\section{Results and discussion}

Table 1 lists the results of the reactions of acylferrocenes $1 \mathbf{a}-\mathbf{c}$ and $\mathbf{2}$ with $\mathrm{SmI}_{2}$ in THF solution. In the presence of $\mathrm{H}_{2} \mathrm{O}$ (11 equiv.), the reaction of ferrocenecarbaldehyde (1a) with $\mathrm{SmI}_{2}\left(2.6\right.$ equiv.) at $0^{\circ} \mathrm{C}$ for a short period $(10 \mathrm{~min})$ gave exclusively ferrocenemethanol (3a) in 93\% yield (Eq. (1)). When 1a was treated with $\mathrm{SmI}_{2}$ (8 equiv.) and water (20 equiv.) in refluxing THF for a prolonged period $(4 \mathrm{~h})$, a deoxygenation product $\mathbf{4 a}$ was obtained. In similar ways (entries 2 and 4), acetylferrocene (1b) was either reduced at $0^{\circ} \mathrm{C}$ to give the alcohol $\mathbf{3 b}(92 \%)$ or deoxygenated at $68^{\circ} \mathrm{C}$ to give $4 \mathbf{b}(85 \%)$. Use of less $\mathrm{SmI}_{2} / \mathrm{H}_{2} \mathrm{O}$ (entry 5) resulted in a decreased yield $(61 \%)$ of $\mathbf{4 b}$. Deoxygenation of benzoylferrocene (Eq. (1)) and 1,1'diacetylferrocene (Eq. (2)) was also successfully carried out to give benzylferrocene (4c) and 1,1'-diethylferrocene (5), respectively. Such deoxygenations could result from the subsequent reduction of the intermediate 
Table 1

The reactions of acylferrocenes $\mathbf{1 a}-\mathbf{c}$ and $\mathbf{2}$ with $\mathrm{SmI}_{2}$ in THF solution

\begin{tabular}{|c|c|c|c|c|c|c|}
\hline Entry & Substrate & $\mathrm{SmI}_{2} /$ substrate molar ratio & Additive & Reaction temp. $/{ }^{\circ} \mathrm{C}$ & Reaction time & Products (yield $/ \%$ ) \\
\hline 1 & 1a & 2.6 & $\mathrm{H}_{2} \mathrm{O}$ (11 equiv.) & 25 & $10 \mathrm{~min}$ & 3a (93) \\
\hline 2 & $\mathbf{1 b}$ & 2.6 & $\mathrm{H}_{2} \mathrm{O}$ (11 equiv.) & 25 & $10 \min$ & $\mathbf{3 b}(92)$ \\
\hline 4 & 1b & 8 & $\mathrm{H}_{2} \mathrm{O}$ (20 equiv.) & 68 & $24 \mathrm{~h}$ & $4 \mathbf{b}(85)$ \\
\hline 5 & 1b & 4 & $\mathrm{H}_{2} \mathrm{O}$ (8 equiv.) & 68 & $4 \mathrm{~h}$ & $4 b(61)$ \\
\hline 6 & 1c & 8 & $\mathrm{H}_{2} \mathrm{O}$ (20 equiv.) & 68 & $16 \mathrm{~h}$ & $4 c(44)$ \\
\hline 9 & $1 b$ & 8 & None & 68 & $48 \mathrm{~h}$ & $7(20)+8(43)^{a}$ \\
\hline 10 & $1 \mathbf{b}$ & 8 & Sieves $(200 \mathrm{mg})$ & 68 & $48 \mathrm{~h}$ & $7(25)+8(36)^{a}$ \\
\hline 11 & $1 \mathbf{b}$ & 8 & HMPA (0.6 equiv.) & 68 & $48 \mathrm{~h}$ & $7(23)+8(36)^{a}$ \\
\hline 12 & 1b & 8 & HMPA (1.4 equiv.) & 68 & $48 \mathrm{~h}$ & $7(18)+8(51)^{a}$ \\
\hline
\end{tabular}

${ }^{a}$ Compound $\mathbf{6}$ existed as a mixture of stereomers (1:1), and compound $\mathbf{8}$ existed as a mixture of geometric isomers in predominance of the $Z$-isomer $(63-86 \%)$.

ferrocenyl alcohols with an excess of $\mathrm{SmI}_{2}$, and these processes might be facilitated by the in situ generated $\mathrm{Sm}$ (III) ion of Lewis acid nature. Indeed, 1-ferrocenylethanol (3b) reacted with $\mathrm{SmI}_{2} / \mathrm{H}_{2} \mathrm{O}$ in refluxing THF gave ethylferrocene (4b), the anticipated deoxygenation product, in a quantitative yield.

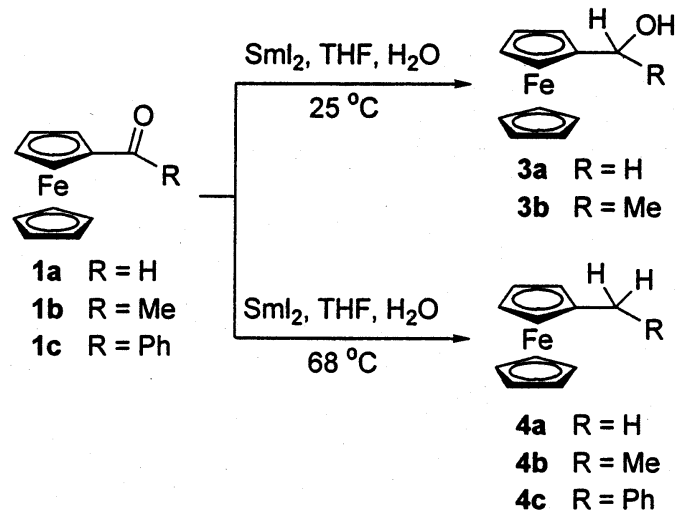

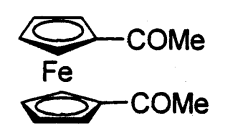

2
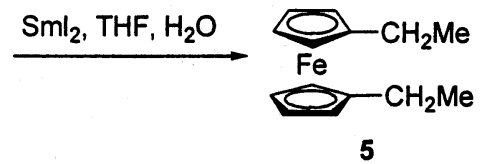

In the absence of $\mathrm{H}_{2} \mathrm{O}$, ferrocenecarbaldehyde underwent a reductive coupling to give the pinacol 6 (Eq. (3)), whereas acetylferrocene yielded 3,3-diferrocenyl-2-butanone (7) and 2,3-diferrocenyl-2-butene (8) on treatment with $\mathrm{SmI}_{2}$ in refluxing THF (Eq. (4)). The diol 6 existed as a mixture of two stereomers in equal amounts, whereas the alkene $\mathbf{8}$ existed as a mixture of geometric isomers with a predominance of the $Z$-isomer $(63-86 \%)$. The configuration of isomers was determined by analysis of their ${ }^{1} \mathrm{NMR}$ spectra. The signals of $Z \mathbf{- 8}$ occurred at higher fields than the corresponding resonances of $E$-isomer. A previously reported reaction [8] of acetylferrocene with $\mathrm{Zn} / \mathrm{TiCl}_{4}$ gives 8 with an $E / Z$ ratio of 3 . The $Z / E$ selectivity might be attributable to the kinetic control of individual reducing agent in the reductive olefination. By comparison of entry 9 with entries $10-12$, the yields and $Z / E$ ratio were slightly changed when acetylferrocene was treated with $\mathrm{SmI}_{2}$ in the presence of molecular sieves or hexamethylphosphoramide.

The pinacol 6 was unstable; it was easily oxidized to ferrocenecarbaldehyde (the parent aldehyde 1a) on standing. Compounds $\mathbf{7}$ and $\mathbf{8}$ could result from the same intermediate of the putative pinacol A (or the corresponding samarium pinacolate), which might rearrange subsequently to give the ketone 7 or react further with $\mathrm{SmI}_{2}$ to give the alkene 8 (Eq. (4)). The pinacol $\mathbf{A}$ was previously found in the reaction of acetylferrocene with electrochemically generated sodium amalgam [9], but not with magnesium amalgam [10]. The pinacol $\mathbf{A}$ can be oxidized, back to acetylferrocene on exposure to the air $[4 b, 9]$. Treatment of $\mathbf{A}$ with $\mathrm{HClO}_{4}$ results in a rearrangement to give the butanone $7[4 \mathrm{~b}, 9]$.
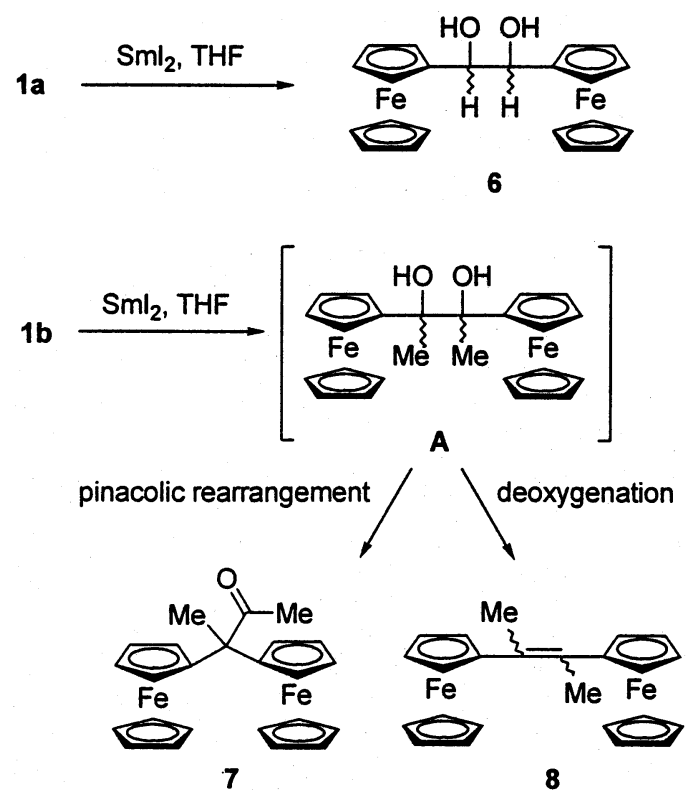


\section{Experimental}

\subsection{General methods}

Melting points are uncorrected. Chemical shifts are reported relative to $\mathrm{CHCl}_{3}\left[\delta_{\mathrm{H}} 7.26, \delta_{\mathrm{C}}\right.$ (central line of t) 77.0]. All reactions requiring anhydrous conditions were conducted in flame-dried apparatus under an atmosphere of nitrogen. Syringes and needles for the transfer of reagents were dried at $120^{\circ} \mathrm{C}$ and allowed to cool in a desiccator over $\mathrm{P}_{2} \mathrm{O}_{5}$ before use. THF was distilled from sodium benzophenone ketyl.

\subsection{Representative procedure for reduction of acylferrocenes}

A deep blue $\mathrm{SmI}_{2}$ solution $(0.1 \mathrm{M}, 1.8 \mathrm{mmol})$ was prepared by treatment of $\mathrm{Sm}(330 \mathrm{mg}, 2.2 \mathrm{mmol})$ with 1,2-diiodoethane $(500 \mathrm{mg}, 1.8 \mathrm{mmol})$ in anhydrous THF (18 ml) for $1.5 \mathrm{~h}$ at room temperature (r.t.). After addition of $\mathrm{H}_{2} \mathrm{O}(135 \mathrm{mg}, 7.5 \mathrm{mmol})$, the mixture was cooled in an ice bath, and a solution of $\mathbf{1 b}(160 \mathrm{mg}, 0.7$ $\mathrm{mmol})$ in THF $(5 \mathrm{ml})$ was added. After stirring for 10 $\min$ at $0^{\circ} \mathrm{C}$, the reaction was quenched by ice water $(2$ $\mathrm{ml})$. The mixture was filtered through a pad of silica gel column, and the filtrate was concentrated to give a practically pure product of $\mathbf{3 b}(148 \mathrm{mg}, 92 \%)$.

\subsubsection{Ferrocenylmethanol [4b], $\mathbf{3 a}$}

According to the representative procedure (Section 3.2 ), ferrocenecarbaldehyde (150 $\mathrm{mg}, 0.7 \mathrm{mmol})$ was treated with $\mathrm{SmI}_{2}$ in THF at $0^{\circ} \mathrm{C}$ for $10 \mathrm{~min}$ to give 3a (141 mg, 93\%). ${ }^{1} \mathrm{H}-\mathrm{NMR}\left(\mathrm{CDCl}_{3}, 200 \mathrm{MHz}\right) \delta 4.30(2$ $\mathrm{H}, \mathrm{s}), 4.21(2 \mathrm{H}, \mathrm{m}), 4.15(5 \mathrm{H}, \mathrm{s}), 4.14(2 \mathrm{H}, \mathrm{m}), 1.89$ $(1 \mathrm{H}, \mathrm{s}) .{ }^{13} \mathrm{C}-\mathrm{NMR}\left(\mathrm{CDCl}_{3}, 50 \mathrm{MHz}\right) \delta 60.6,67.9(2 \mathrm{C})$, 68.2 (7 C), 88.1.

\subsubsection{1-Ferrocenylethanol [4a], $3 \boldsymbol{b}$}

${ }^{1} \mathrm{H}-\mathrm{NMR}\left(\mathrm{CDCl}_{3}, 300 \mathrm{MHz}\right) \delta 4.56(1 \mathrm{H}, \mathrm{q}, J=6.3$ $\mathrm{Hz}), 4.17-4.06(9 \mathrm{H}, \mathrm{m}), 2.19(1 \mathrm{H}, \mathrm{s}), 1.41(3 \mathrm{H}, \mathrm{d}$, $J=6.3 \mathrm{~Hz}) .{ }^{13} \mathrm{C}-\mathrm{NMR}\left(\mathrm{CDCl}_{3}, 50 \mathrm{MHz}\right) \delta 23.5,65.3$, 65.8, 66.1, 67.6, 67.7, 68.1 (5 C), 94.3.

\subsection{Representative procedure for deoxygenation of acylferrocenes}

A deep blue $\mathrm{SmI}_{2}$ solution $(0.11 \mathrm{M}, 8.0 \mathrm{mmol})$ was prepared by treatment of Sm $(1.20 \mathrm{~g}, 8.0 \mathrm{mmol})$ with 1,2-diiodoethane $(2.25 \mathrm{~g}, 8.0 \mathrm{mmol})$ in anhydrous THF $(70 \mathrm{ml})$ for $1.5 \mathrm{~h}$ at r.t. After addition of $\mathrm{H}_{2} \mathrm{O}(360 \mathrm{mg}$, $20 \mathrm{mmol})$, a solution of $1 \mathrm{a}(214 \mathrm{mg}, 1.0 \mathrm{mmol})$ in THF $(10 \mathrm{ml})$ was added in one portion. The mixture was heated under reflux for $4 \mathrm{~h}$. The serum cap was removed, and hexane $(20 \mathrm{ml})$ was added. The resulting precipitates were removed by passing through a pad of silica gel, and the crude product was obtained by elution with EtOAc. Further purification by silica gel column (3:97 EtOAc-hexane) afforded 4a (140 mg, $70 \%)$.

\subsubsection{Methylferrocene [6f], $\mathbf{4 a}$}

${ }^{13} \mathrm{C}-\mathrm{NMR}\left(\mathrm{CDCl}_{3}, 50 \mathrm{MHz}\right) \delta 14.8,67.1$ (2 C), 68.5 (5 C), 69.1 (2 C), 83.9. Anal. Calc. for $\mathrm{C}_{11} \mathrm{H}_{12} \mathrm{Fe}$ : C, 66.04; H, 6.05. Found: C, 65.85; H, 6.12.

\subsubsection{Ethylferrocene [6f], $\mathbf{4 b}$}

According to the representative procedure (Section 3.3 ), acetylferrocene (228 $\mathrm{mg}, 1 \mathrm{mmol})$ was treated with $\mathrm{SmI}_{2}$ in refluxing THF for $48 \mathrm{~h}$ to give $4 \mathbf{b}(182 \mathrm{mg}$, $85 \%)$ after chromatography on a silica gel column (3:97 EtOAc-hexane).

Compound $\mathbf{4 b}$ was also prepared from the alcohol $\mathbf{3 b}$ by the following procedure. A mixture of $\mathbf{3 b}(230 \mathrm{mg}, 1$ $\mathrm{mmol})$ and water $(98 \mathrm{mg}, 5.5 \mathrm{mmol})$ in THF $(10 \mathrm{ml})$ was added to a THF solution $(40 \mathrm{ml})$ of $\mathrm{SmI}_{2}(3.6$ mmol). The mixture was heated under reflux for 50 min, cooled, and filtered through a pad of silica gel by elution with EtOAc-hexane (1:1) to give a practically pure sample of $\mathbf{4 b}(211 \mathrm{mg}, 99 \%)$ as shown by ${ }^{1} \mathrm{H}$ - and ${ }^{13} \mathrm{C}$-NMR analyses. ${ }^{13} \mathrm{C}$-NMR $\left(\mathrm{CDCl}_{3}, 50 \mathrm{MHz}\right) \delta$ 14.6, 22.2, 66.8 (2 C), 67.4 (2 C), 68.3 (5 C), 91.0. Anal. Calc. for $\mathrm{C}_{12} \mathrm{H}_{14} \mathrm{Fe}$ : C, 67.30; H, 6.59. Found: C, 67.05; $\mathrm{H}, 6.50$.

\subsubsection{Benzylferrocene [6f], $\mathbf{4 c}$}

According to the representative procedure (Section 3.3), benzoylferrocene ( $290 \mathrm{mg}, 1 \mathrm{mmol})$ was treated with $\mathrm{SmI}_{2}$ in refluxing THF for $16 \mathrm{~h}$ to give $4 \mathrm{c}(122 \mathrm{mg}$, $44 \%)$ after chromatography on a silica gel column (3:97 EtOAc-hexane). ${ }^{13} \mathrm{C}-\mathrm{NMR}\left(\mathrm{CDCl}_{3}, 50 \mathrm{MHz}\right) \delta 36.0$, 67.5 (2 C), 68.6 (7 C), 87.9, 125.8, 128.2 (2 C), 128.3 (2 C), 141.5. FAB-MS $m / z 276\left(\mathrm{M}^{+}\right)$.

\subsubsection{1,1'-Diethylferrocene [6f], 5}

According to the representative procedure (Section $3.3), 1,1^{\prime}$-diacetylferrocene $(270 \mathrm{mg}, 1 \mathrm{mmol})$ was treated with $\mathrm{SmI}_{2}$ in refluxing THF for $16 \mathrm{~h}$ to give 5 (162 mg, 67\%) after chromatography on a silica gel column by elution with hexane and EtOAc-hexane (3:97). ${ }^{13} \mathrm{C}-\mathrm{NMR}\left(\mathrm{CDCl}_{3}, 50 \mathrm{MHz}\right) \delta 15.4(2 \mathrm{C}), 22.7$ (2 C), 68.1 (4 C), 68.5 (4 C), 91.6 (2 C). FAB-MS $m / z$ $242\left(\mathrm{M}^{+}\right)$.

\subsection{1,2-Diferrocenyl-1,2-ethanediol [11], 6}

Ferrocenecarbaldehyde (214 mg, $1 \mathrm{mmol})$ was treated with $\mathrm{SmI}_{2}(8 \mathrm{mmol})$ in anhydrous THF under reflux for $48 \mathrm{~h}$. After addition of ice water $(50 \mathrm{ml})$, the mixture was extracted with $\mathrm{CHCl}_{3}(30 \mathrm{ml} \times 10)$. The extracts were combined, washed with water, concentrated, and crystallized from $\mathrm{MeOH}-\mathrm{H}_{2} \mathrm{O}$ to give the pinacols 6 (90 $\mathrm{mg}, 42 \%)$ as a mixture of two stereomers (1:1). ${ }^{1} \mathrm{H}$ - 
NMR $\left(\mathrm{CDCl}_{3}, 200 \mathrm{MHz}\right) \delta 2.24 / 2.51(2 \mathrm{H}, \mathrm{s}, \mathrm{OH})$, 3.88/4.06 (4 H, m), 4.12/4.22 (4 H, m), $4.17(10 \mathrm{H}, \mathrm{s})$, $4.24 / 4.30(2 \mathrm{H}, \mathrm{s})$. FAB-MS $m / z 430\left(\mathrm{M}^{+}\right)$.

\subsection{The reaction of acetylferrocene with $\mathrm{SmI}_{2}$ in the} absence of water.

Acetylferrocene (228 mg, $1 \mathrm{mmol}$ ) was treated with $\mathrm{SmI}_{2}(8 \mathrm{mmol})$ in anhydrous THF under reflux for $48 \mathrm{~h}$. Hexane was added, and the resulting precipitates were removed by passing through a pad of silica gel. The filtrate was concentrated and chromatographed on a silica gel column by elution with hexane and EtOAc-hexane (5:95) to give the ketone 7 (44 mg, 20\%) and the alkene 8 (71 $\mathrm{mg}, 43 \%)$.

\subsubsection{3,3-Diferrocenyl-2-butanone [9], 7}

${ }^{1} \mathrm{H}-\mathrm{NMR}\left(\mathrm{CDCl}_{3}, 200 \mathrm{MHz}\right) \delta 1.86(3 \mathrm{H}, \mathrm{s}), 2.04(3$ $\mathrm{H}, \mathrm{s}), 4.06(4 \mathrm{H}, \mathrm{m}), 4.08(10 \mathrm{H}, \mathrm{s}), 4.16(4 \mathrm{H}, \mathrm{m})$. ${ }^{13} \mathrm{C}-\mathrm{NMR}\left(\mathrm{CDCl}_{3}, 50 \mathrm{MHz}\right) \delta 24.1,27.6,50.7,66.8,67.0$, 67.7, 67.8, 68.8 (4 C), 93.5 (2 C), 207.2. FAB-MS $m / z 440$ $\left(\mathrm{M}^{+}\right)$.

\subsubsection{2,3-Diferrocenyl-2-butene [8], $\boldsymbol{8}$}

${ }^{1} \mathrm{H}-\mathrm{NMR}\left(\mathrm{CDCl}_{3}, 200 \mathrm{MHz}, Z\right.$-isomer $) \delta 2.11(6 \mathrm{H}$, s), $3.88(4 \mathrm{H}, \mathrm{m}), 4.02(4 \mathrm{H}, \mathrm{m}), 4.05(10 \mathrm{H}, \mathrm{s}) ;{ }^{1} \mathrm{H}-\mathrm{NMR}$ $\left(\mathrm{CDCl}_{3}, 200 \mathrm{MHz}, E\right.$-isomer $) \delta 2.15(6 \mathrm{H}, \mathrm{s}), 4.15(10$ $\mathrm{H}, \mathrm{s}), 4.22(4 \mathrm{H}, \mathrm{m}), 4.31(4 \mathrm{H}, \mathrm{m})$. FAB-MS $m / z 424$ $\left(\mathrm{M}^{+}\right)$. Anal. Calc. for $\mathrm{C}_{24} \mathrm{H}_{24} \mathrm{Fe}_{2}: \mathrm{C}, 67.96 ; \mathrm{H}, 5.70$. Found: C, 67.67; H, 5.60.

\section{Acknowledgements}

We thank the National Science Council of the Republic of China for financial support (NSC 88-2113-M-002-023).

\section{References}

[1] For leading reviews: (a) N.R. Natale, Org. Prep. Proc. Int. 15 (1983) 387. (b) H.B. Kagan, J.L. Namy, Tetrahedron 42 (1986)
6573. (c) H.B. Kagan, Inorg. Chim. Acta 140 (1987) 3. (d) H.B. Kagan, New J. Chem. 14 (1990) 453. (e) J. Inanaga, Rev. Heteroatom Chem. 3 (1990) 75. (f) G.A. Molander, in: B.M. Trost, I. Fleming, (Eds.), Comprehensive Organic Synthesis, vol. 1, Pergamon, Oxford, 1991, pp. 251-282. (g) J.A. Soderquist, Aldrichimia Acta 24 (1991) 15. (h) G.A. Molander, Chem. Rev. 92 (1992) 29. (i) N.E. Brandukova, Y.S. Vygodskii, S.V. Vinogradova, Russ. Chem. Rev. 63 (1994) 345. (j) G.A. Molander, C.R. Harris, Chem. Rev. 96 (1996) 307. (k) G.A. Molander, C. R. Harris, Tetrahedron 54 (1998) 3321.

[2] (a) J.L. Namy, J. Souppe, H.B. Kagan, Tetrahedron Lett. 24 (1983) 765. (b) N. Taniguchi, N. Kaneta, M. Uemura, J. Org. Chem. 61 (1996) 6088. (c) L. Lu, J.-M. Fang, G.-H. Lee, Y. Wang, J. Chin. Chem. Soc. 44 (1997) 279. (d) E. Leonard, E. Dunach, J. Perichon, J. Chem. Soc. Chem. Commun. (1989) 276. $\mathrm{SmCl}_{3}$ catalyzed electrolyses of aromatic aldehydes and ketones in DMF or NMP also give pinacols.

[3] M. Rosenblum, Chemistry of the Iron Group Metallocenes, Wiley, New York, 1965.

[4] (a) F.S. Arimoto, A.C. Haven, Jr., J. Am. Chem. Soc. 77 (1955) 6295. (b) N. Weliky, E.S. Gould, J. Am. Chem. Soc. 79 (1957) 2742. (c) P.J. Graham, R.V. Lindsey, G.W. Parshal, M.L. Peterson, G.M. Whitman, J. Am. Chem. Soc. 79 (1957) 3416.

[5] (a) M.D. Rausch, M. Vogel, H. Rosenberg, J. Org. Chem. 22 (1957) 903. (b) K.L. Rinehart, R.J. Curby, P.E. Sokol, J. Am. Chem. Soc. 79 (1957) 3420. (c) M. Rosenblum, R.B. Woodward, J. Am. Chem. Soc. 80 (1958) 5443.

[6] (a) E.L. DeYoung, J. Org. Chem. 26 (1961) 1312. (b) J.M. Osgerby, P.L. Pauson, J. Chem. Soc. (1961) 4604. (c) B.R. Brown, A.M.S. White, J. Chem. Soc. (1957) 3755. (d) R.F. Nystrom, C.R.A. Berger, J. Am. Chem. Soc. 80 (1958) 2896. (e) S. Bhattacharyya, Synth. Commun. 26 (1996) 4647. (f) S. Bhattacharyya, J. Chem. Soc. Dalton Trans. (1996) 4617. (g) S. Bhattacharyya, Synlett 1995, 971. (h) S. Bhattacharyya, J. Org. Chem. 63 (1998) 7101.

[7] A. Togni, T. Hayashi (Eds.), Ferrocenes, VCH, Weinheim, 1995.

[8] (a) H. Patin, R. Dabard, Bull. Soc. Chim. Fr. (1973) 2413. (b) H. Patin, R. Dabard, Bull. Soc. Chim. Fr. (1973) 2416. (c) D. Lenoir, H. Burghard, J. Chem. Res. (S) (1980) 396 and J. Chem. Res. (M) (1980) 4715. (d) T.-Y. Dong, T.-J. Ke, S.-M. Peng, S.-K. Yeh, Inorg. Chem. 28 (1989) 2103.

[9] M. Lacan, Z. Ibrisagic, Croatica Chem. Acta 46 (1974) 107.

[10] (a) L.R. Moffett, J. Org. Chem. 29 (1964) 3726. (b) P.L. Pauson, W.E. Watts, J. Chem. Soc. (1962) 3880.

[11] A.N. Nesmeyanov, E.G. Perevalova, T.T. Tsiskaridze, Izv. Akad. Nauk. SSSR Ser. Khim. 12 (1966) 2209. 